\title{
Property Changes in Potato Tubers (Solanum tuberosum L.) During Cold Storage at 0 and $10^{\circ} \mathrm{C}$
}

\author{
Murata Yosuke*, Kevin F. Yaptenco**, Noguchi Tomohiro***, Suzuki Toshiro***, \\ Sato Hiroaki**, Matsumoto Shinji*** and TAKano Katsumi* \\ * Department of Applied Biology and Chemistry, Faculty of Applied Bioscience, \\ Tokyo university of Agriculture \\ 1-1-1, Sakuragaoka, Setagaya-ku, Tokyo 156-8502 \\ ** Department of Food Science and Technology, Faculty of Bioindustry, \\ Tokyo University of Agriculture \\ 196, Yasaka, Abashiri-shi, Hokkaido 099-2493 \\ *** Food Processing Center, Faculty of Applied Bioscience, \\ Tokyo University of Agriculture \\ 1-1-1, Sakuragaoka, Setagaya-ku, Tokyo 156-8502
}

\begin{abstract}
The effect of storage at $0^{\circ} \mathrm{C}$ and $10^{\circ} \mathrm{C}$ on physical and biochemical parameters of 'Danshaku' tubers was monitored to provide baseline information on this cultivar's storage behavior. Sugar and starch level, weight loss, firmness, specific gravity, tissue color, fatty acid composition of phospholipicls, sprouting and respiration rate, starch content, particle size, and pasting properties were monitored. Sugar accumulation occurred in tubers stored at $0^{\circ} \mathrm{C}$, while minimal sugar accumulation and severe sprouting and weight loss was observed for tubers at $10^{\circ} \mathrm{C}$. Tubers stored at $10^{\circ} \mathrm{C}$ were consistently softer due to weight loss. No significant changes were observed in tissue color between storage treatments. Double bond index of tissue increased after 30 days at $0^{\circ} \mathrm{C}$, indicating an adjustment to cold stress to increase tolerance. Sprouting occurred earlier in tubers stored at $10^{\circ} \mathrm{C}$; final respiration was also higher compared to tubers stored at $0^{\circ} \mathrm{C}$. Starch content and particle size decreased during storage; however, a greater reduction was observed at $0^{\circ} \mathrm{C}$ storage.
\end{abstract}

(Received Mar. 24, 2000; Accepted Apr. 24, 200)

Potatoes are one of the most important crops in the world, making up one-half of the tubers and roots produced world-wide. Over one billion people consume potatoes, with 500 million consumers in developing countries alone. The average annual world production increased from 275 million tons per year $(1987 \sim 1989)^{* 1} 1$ to 295 million tons (1995 1997), making it the fourth most important crop among 21 major food crops. Production area from 1995 1997 reached an average of 18 million hectares. Fifty-four percent of world production was consumed as food, while $19 \%$ went to feed, $12 \%$ for seeds, $8 \%$ for processing, and $8 \%$ for other uses ${ }^{* 2}$.

* 1 From "Potatoes in the 1990s: Situation and Prospects of the World Potato Economy", a webpage of the Food and Agriculture Organization of the United Nations located at http://www.fao.org/es/esc/escb/root\&tu/pote.htm.

* 2 From "CIP Potato Facts : Potato Indicators", a web page of the International Potato Center located at http ://www. cipotato.org/market/potatofacts/potind.htm. 
Potato utilization world-wide is moving away from the fresh and livestock feed market towards processed products that include French fries, chips, and frozen and dehydrated potatoes. More than half of the annual crop in the United States is processed. A sharp increase in processing is also happening in Western and Eastern Europe, the former USSR, and developing countries such as Argentina, China, Colombia, and Egypt. Higher incomes, new technology, and tourism are stimulating expansion in developed countries, while urbanization, new dietary habits, and increasing female employment fuel growth in developing countries. Present trends show that among developing countries, Asia will become a major potato processor, especially in Turkey, China, India, Indonesia, and Vietnam*3.

Potatoes are stored at $10 \sim 12^{\circ} \mathrm{C}$ when intended for the chip industry. Chemical inhibitors are sprayed on the tubers to prevent sprouting. However, with increasing health consciousness among consumers, the use of chemicals on food products is becoming unpopular. Lower storage temperatures can inhibit sprouting without the use of chemicals. However, accumulation of reducing sugars and sucrose levels is a common occurrence during storage below $10^{\circ} \mathrm{C}$. This phenomenon is known as low temperature sweetening (LTS). High sugar levels are not acceptable for processing potatoes due to the Maillard reaction during frying which lowers the value of the product. This reaction, which involves the condensation of reducing sugars with compounds containing free amine groups, turns the potato dark and imparts a bitter flavor ${ }^{1,2}$.

Aside from sugar levels, many other physical and biochemical changes occur during storage that can affect the quality of processed products. Starch properties, tuber weight, and specific gravity change as respiration and transpiration mobilize starch and release moisture. This study was conducted with the purpose of establishing baseline information on 'Danshaku' tuber quality changes occurring during low-temperature storage. Knowledge of these changes can later serve as the basis for more detailed studies on tuber physiology, biochemistry and quality testing.

\section{Materials and Methods}

'Danshaku' tubers were washed, allowed to dry and stored in corrugated cartons at $0^{\circ} \mathrm{C}$ and $10^{\circ} \mathrm{C}$. Tubers were sampled after $0,16,30,50,70$ and 105 days of storage for sugars, specific gravity, weight loss, tissue color, and firmness. Pooled samples were taken from four tubers for sugar analysis by high performance liquid chromatography (HPLC).

\section{Sugar analysis}

Sugar was extracted by boiling homogenized potato tissue in $80 \%$ ethanol solution for one hour. Extracts were filtered through \#2 Whatman filter paper and stored at $4^{\circ} \mathrm{C}$. An HPLC fitted with a Shodex Sugar SPO 810 column was used with distilled water as eluent. Column temperature was set at $80^{\circ} \mathrm{C}$ and flow rate at $0.7 \mathrm{~m} \ell / \mathrm{min}$. Sucrose, glucose, and fructose were determined by comparing sample peak heights with standard sugar solutions.

\section{Specific gravity}

Specific gravity (SG) was determined by weighing tubers in air, and then in water using a digital balance. SG was calculated as wht in air/ (wht in air-wht in water). Weight loss was expressed as a percentage of the change in weight with time over the original weight.

\section{Tissue color and tuber hardness}

Tissue color was recorded in terms of Hunter L-a-b color coordinates, using a Minolta CT-210 color meter. Three replicate readings were taken for each tuber. Tuber hardness was measured using a hand-held Universal Hardness meter; tubers were tested three times at random locations and the results averaged.

\section{Statistical analysis}

Effect of storage time and temperature on SG, weight loss, firmness, and tissue color was

* 3 From "Bright Future for Potato Processing and Trade", a web page located at http ://www.cipotato.org/Projects/ potato/gsca\&iap/potpro.htm 
analyzed by two-way analysis of variance (ANOVA). Correlations between sugar levels and SG were analyzed by simple linear regression and analysis of variance. For all statistical analyses, the level of significance was set at $\mathrm{p}=0.05$.

\section{Fatty acid analysis}

Fatty acid composition of phospholipids in tuber tissue was determined by chloroform: methanol extraction (1:1) for two hours. Phospholipid fraction was separated from the total lipid fraction using a Waters Sep-Pak silicic acid column. Lipids were methyl-esterized and analyzed by gas chromatography using a ULBON-SS10 capillary column with flame ionization detector. Column temperature was set at $180^{\circ} \mathrm{C}$ while injector temperature was set at $210^{\circ} \mathrm{C}$. Lipids were sampled at $0,30,60$, and 90 days of storage. The double bond index (DBI) was used to express the ratio of unsaturated to saturated fatty acids and was expressed $\frac{2 \cdot\left[\% \mathrm{C}_{18: 2}\right]+3 \cdot\left[\% \mathrm{C}_{18: 2}\right]}{\% \mathrm{C}_{16: 0}+\% \mathrm{C}_{18: 0}} \mathrm{as}^{3}$.

\section{Starch content and particle size}

Ten grams of potato tissue was boiled in ethanol for one hour at $100^{\circ} \mathrm{C}$ to extract alcohol-insoluble solids (AIS). Ten mg of AIS was gelatinized and shaken in $6.5 \mathrm{~m} \ell$ of $52 \%$ perchloric acid; after centrifuging, the supernatant was analyzed by phenol-sulfate method to determine total starch content. Starch particle size distribution was measured from a $10 \mathrm{mg}$ starch sample suspended in $1 \mathrm{~m} \ell$ of distilled water, using a Luzex F image analyzer (NIRECO Co.).

\section{Viscosity}

Measurements were performed at 0 and 90 days of storage. Viscosity was measured using a Rapid Visco-Analyzer (Newport Scientific RVA-3D Plus) by mixing $2 \mathrm{~g}$ of starch with $25 \mathrm{~m} \ell$ of distilled water. Samples were scanned from $50^{\circ} \mathrm{C}$ to $95^{\circ} \mathrm{C}$, held for 150 seconds at $95^{\circ} \mathrm{C}$, and cooled to $50^{\circ} \mathrm{C}$. Measurements were performed at 0 and 90 days of storage. Maximum viscosity, breakdown, final viscosity, and setback were recorded.

\section{Respiration rate}

For determination of respiration rate, about 400 $\mathrm{g}$ of potato was placed in a 3-liter polyethylene bag and the rate of $\mathrm{O}_{2}$ consumption was measured using a FO-960 flourescence oxygen concentration meter (Automatic System Research Co., Ltd.). Sampling was performed at $0,7,12,17,25,31,42$, and 60 days of storage.

\section{Results and Discussion}

\section{Sugare levels}

Invertase is thought to contribute to LTS by hydrolyzing sucrose into glucose and fructose. Past studies have correlated acid invertase activity with glucose and fructose accumulation, based on enzyme activity during LTS and an equimolar glucose: fructose ratio. Different turnover rates of glucose and fructose may cause the ratio to deviate from exact equimolarity ${ }^{4,5}$. Since sucrose is produced first, a lag period for reducing sugar accumulation may be expected during cold storage $^{6)}$. Sucrose can reach $5 \%$ within 6 hours of moving tubers from $10^{\circ} \mathrm{C}$ to $2^{\circ} \mathrm{C}$, while reducing sugars start increasing only after $1 \sim 2$ days of storage ${ }^{7}$. In this study, sucrose accumulation started immediately and peaked after30days, fluctuating at $\approx 7.5 \mathrm{mg} / \mathrm{g}$ thereafter (Fig.1). Glucose and fructose accumulation started only after 16 days at $0^{\circ} \mathrm{C}$.

\section{Specific gravity, weight loss and firmness}

Under normal storage conditions (relative humidity $<100 \%$ ), specific gravity will not change or increase by a relatively small degree due to moisture $\operatorname{loss}^{8)}$. Average specific gravity $(\mathrm{SG}) \pm$ standard deviation (SD) of 'Danshaku' was $1.0312 \pm 0.0164$. Final SG was 1.0779 and 1.0746 for $0^{\circ} \mathrm{C}$ and $10^{\circ} \mathrm{C}$ storage, respectively. For both storage treatments, SG increased significantly $(\mathrm{p}<0.01)$ during the first month of storage. SG stabilized after this period, remaining more or less constant until the end of storage (Fig. 2). Storage temperature had no significant effect on SG by two-way ANOVA $(\mathrm{p}>0.05)$. In tubers stored at $0^{\circ} \mathrm{C}$, sugars were positively correlated with specific gravity, although this was not significant at $\mathrm{p}>0.05$ (data not shown). These results contradict previous studies where sugars were inversely related to specific gravity: as sugar 

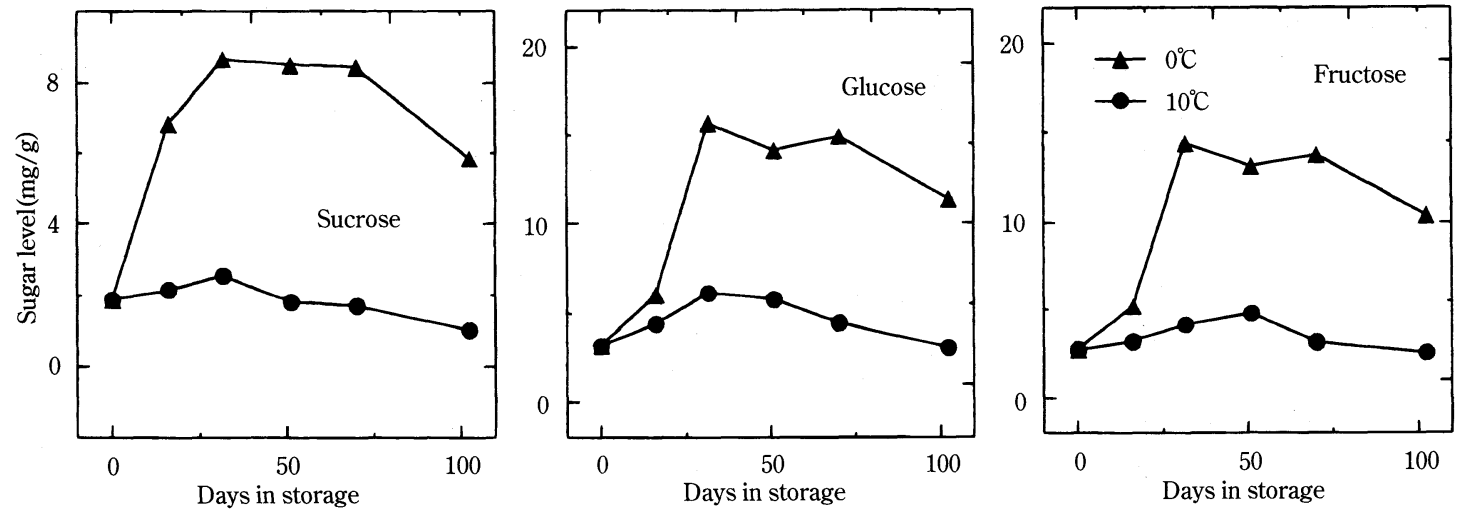

Fig. 1 Suger levels in 'Danshaku' tubers during storage.

Each data point is a pooled sample from at least three tubers.

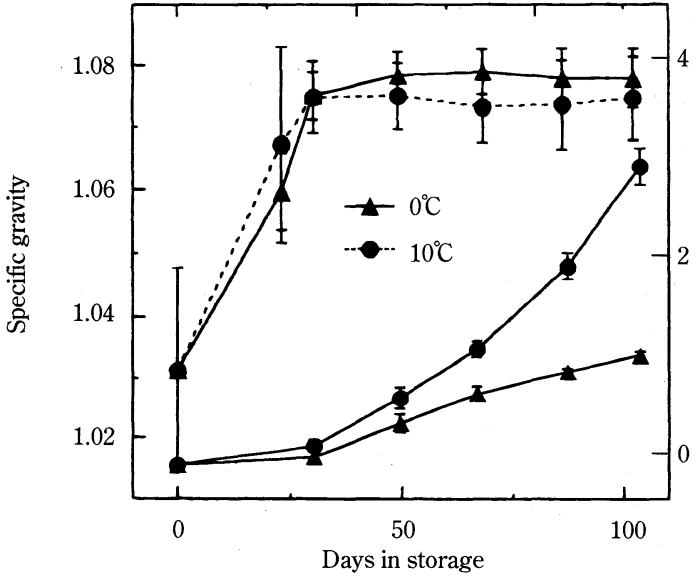

Fig. 2 Specific gravity and weight loss of 'Danshaku' tubers during storage.

Each data point shows the mean $\pm \mathrm{SD}$ of at least three tubers.

levels increase, SG decreases ${ }^{9}$. A possible explanation may be moisture loss that compensated for the conversion of starch into sugars. Sugars in tubers stored at $10^{\circ} \mathrm{C}$ did not correlate significantly with SG possibly due to physiological and biochemical changes occurring in the tubers during sprouting.

All tubers lost a significant amount of weight during storage, regardless of storage temperature $(p<0.05)$ (Fig. 3). However, tubers stored at $10^{\circ} \mathrm{C}$ significantly lost more weight $(\mathrm{p}<0.05)$ compared to those stored at $0^{\circ} \mathrm{C}$. Rate of weight loss was
Table 1 Fatty acid composition of the phospholipid fraction in 'Danshaku' tuber tissue during cold storage

\begin{tabular}{lcccccc}
\hline Cultivar/storage & \multirow{2}{*}{$\begin{array}{l}\text { Storage } \\
\text { temperature }\end{array}$} & \multicolumn{5}{c}{ \% of total acids } \\
\cline { 3 - 7 } & (days) & $\mathrm{C}_{16: 0}$ & $\mathrm{C}_{18: 0}$ & $\mathrm{C}_{18: 2}$ & $\mathrm{C}_{18: 3}$ & Total \\
\hline 'Danshaku' & 0 & 25.5 & 3.0 & 55.5 & 13.7 & 97.7 \\
$0{ }^{\circ} \mathrm{C}$ & 30 & 26.5 & 3.0 & 53.0 & 15.4 & 97.9 \\
& 60 & 24.6 & 3.4 & 49.4 & 20.1 & 97.5 \\
& 90 & 24.0 & 3.4 & 49.3 & 20.5 & 97.3 \\
\hline 'Danshaku' & 0 & 25.5 & 3.0 & 55.5 & 13.7 & 97.7 \\
$10^{\circ} \mathrm{C}$ & 30 & 25.4 & 3.5 & 55.6 & 13.3 & 97.9 \\
& 60 & 25.1 & 3.4 & 57.1 & 11.9 & 97.4 \\
& 90 & 24.1 & 3.2 & 55.8 & 14.3 & 97.4 \\
\hline 'Russet Burbank' & 60 & 26.3 & 7.2 & 48.9 & 13.1 & 95.5 \\
$4{ }^{\circ} \mathrm{C}^{3)}$ & & & & & & \\
\hline
\end{tabular}

also greater at $10^{\circ} \mathrm{C}$ storage. Storage temperature interacted with storage time to increase weight loss during storage $(\mathrm{p}<0.05)$; weight loss was greater when tubers were stored at the higher temperature. This may be due to sprouting which started after 23 days at $10^{\circ} \mathrm{C}$. After storage for 102 days, tubers stored at $0^{\circ} \mathrm{C}$ and $10^{\circ} \mathrm{C}$ lost $1.21 \%$ and $3.29 \%$ of their original weight, respectively. Potatoes undergo a rest period after harvest where tubers are unable to sprout even if conditions are suitable for growth. This period lasts $5 \sim 20$ weeks and can vary according to 


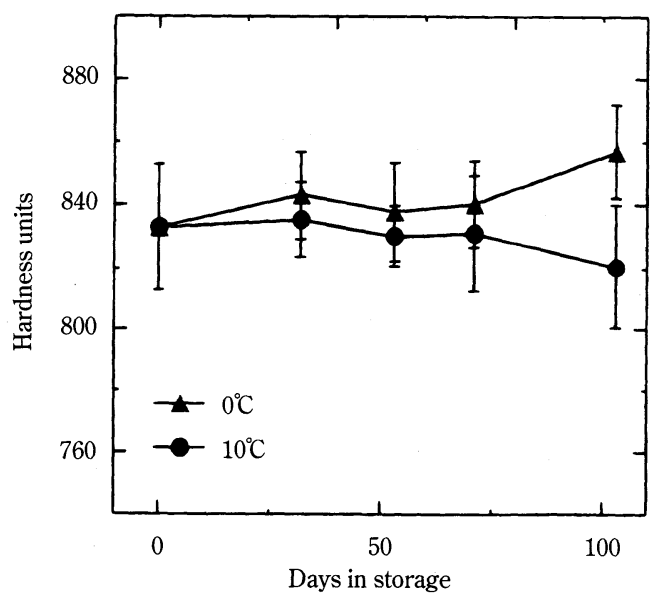

Fig. 3 Firmness of 'Danshaku' tubers during storage.

Each data point shows the mean $\pm \mathrm{SD}$ of at least three tubers.

cultivar, degree of maturity at harvest, presence of disease and even day length during cultivation ${ }^{10,11)}$. 'Danshaku' appeared to have a short rest period, since sprouts appeared after only 3 weeks of storage.

Storage temperature, storage time, and the interaction between these two factors had no significant effect $(p>0.05)$ on tuber firmness, although tubers stored at $10^{\circ} \mathrm{C}$ were consistently softer than those stored at $0^{\circ} \mathrm{C}$ (Fig. 3). Tubers stored at $10^{\circ} \mathrm{C}$ softened slightly during storage, while tubers stored at $0^{\circ} \mathrm{C}$ showed some hardening. The decrease in firmness during $10^{\circ} \mathrm{C}$ storage may be due to the presence of sprouts and the higher storage temperature that enhanced evaporation. Gas could have replaced moisture in the tissue, contributing to softening of the tubers.

\section{Fatty acid composition}

Composition of the phospholipid fraction in tuber tissue is shown in Table 1. C16:0, C18:0, C18:2, and $\mathrm{C}_{18: 3}$ collectively made up more than $97 \%$ of the phospholipid fraction in 'Danshaku' tuber tissue, comparable to previous results on 'Russet Burbank'3). In tubers stored at $10^{\circ} \mathrm{C}$, minimal changes were observed in the levels of each fatty

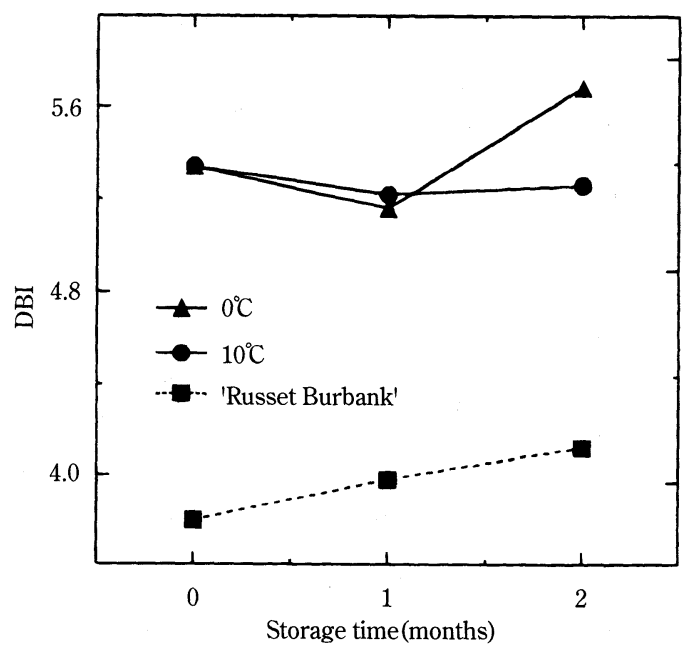

Fig. 4 DBI profile of 'Danshaku' tuber tissue during storange.

Dashed line shows cubic model for 'Russet Burbank' tubers stored at $4{ }^{\circ} \mathrm{C}^{3)}$.

acid. However, in tubers stored at $0^{\circ} \mathrm{C}$, the proportion of $\mathrm{C}_{18: 2}$ increased while $\mathrm{C}_{18: 3}$ decreased during storage; only minimal changes were seen in $\mathrm{C}_{16: 0}$ and $\mathrm{C} 18: 0$. DBI increased in tubers stored at both $0^{\circ} \mathrm{C}$ and $10^{\circ} \mathrm{C}$, indicating a greater degree of unsaturation (Fig.4). This is in apparent contradiction to previous studies where a decrease in unsaturated FA during cold storage or senescence was recorded. However, the variation of DBI of 'Russet Burbank' tubers stored at $4^{\circ} \mathrm{C}$ has been observed to follow a cubic model ${ }^{3)}$. The model showed that maximum DBI occurred after 6 and 32 months, while minimum DBI occurred after 24 months of storage. A portion of the model is shown in Fig. 4, showing that DBI increases during the first three months of cold storage, possibly due to lipid retailoring to increase cold tolerance.

\section{Starch content, partical size and viscosity}

Total starch made up $78.2 \%$ of dry matter in 'Danshaku' tubers prior to storage. When stored at $10^{\circ} \mathrm{C}$ for 90 days, this decreased to $68.3 \% \mathrm{db}$. When stored at $0^{\circ} \mathrm{C}$ for 90 days, starch fell to 31 . $8 \% \mathrm{db}$ (Fig. 5). The average size of a potato starch granule is around $40 \mathrm{~mm}^{12}$. Descriptive 


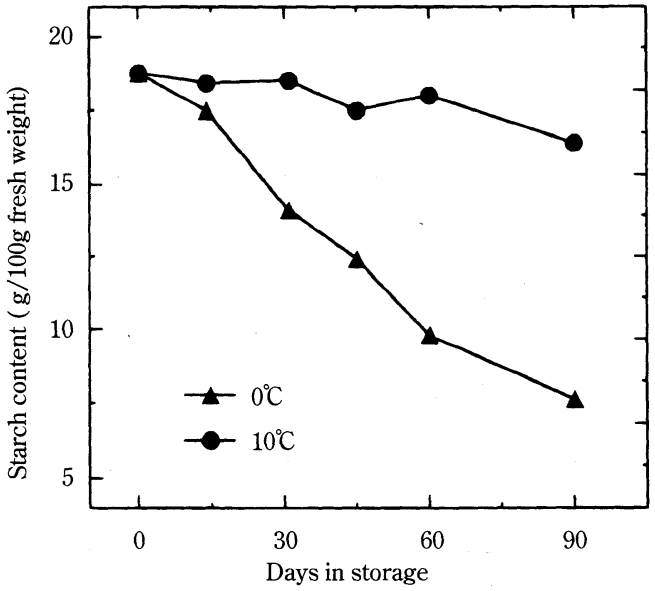

Fig. 5 Total starch content of 'Danshaku' tubers during cold storage.

Table 2 Descriptive statistics of starch particle size in 'Danshaku' tubers

\begin{tabular}{llcr}
\hline $\begin{array}{l}\text { Storage time/ } \\
\text { temperature }\end{array}$ & $\begin{array}{l}\text { Particle } \\
\text { dimension }\end{array}$ & Mean $(\mathrm{mm})$ & SD (mm) \\
\hline Pre-storage & long axis & 34.61 & 17.28 \\
& short axis & 27.84 & 12.24 \\
90days, $0{ }^{\circ} \mathrm{C}$ & long axis & 23.49 & 13.02 \\
& short axis & 18.86 & 9.16 \\
90days, $10{ }^{\circ} \mathrm{C}$ & long axis & 29.88 & 15.94 \\
& short axis & 23.17 & 10.95 \\
\hline
\end{tabular}

statistics of starch particle size distribution are shown in Table 2. Granule size of starch decreased during $10^{\circ} \mathrm{C}$ storage as starch was mobilized for sprouting; however, a greater reduction was observed in tubers stored at $0^{\circ} \mathrm{C}$ which underwent LTS. Therefore, more starch was mobilized for LTS compared to sprouting as seen from the greater reduction in total starch levels and particle size. Normally, when simultaneous shear and high temperature is used to disrupt starch granules, viscosity increases to a maximum and then falls. Maximum granule swelling is reached at peak viscosity, after which fragmentation of granules and dissolution of polymers cause the viscosity to drop. Another theory is that peak viscosity occurs at maximum swelling and hydration, with further shearing

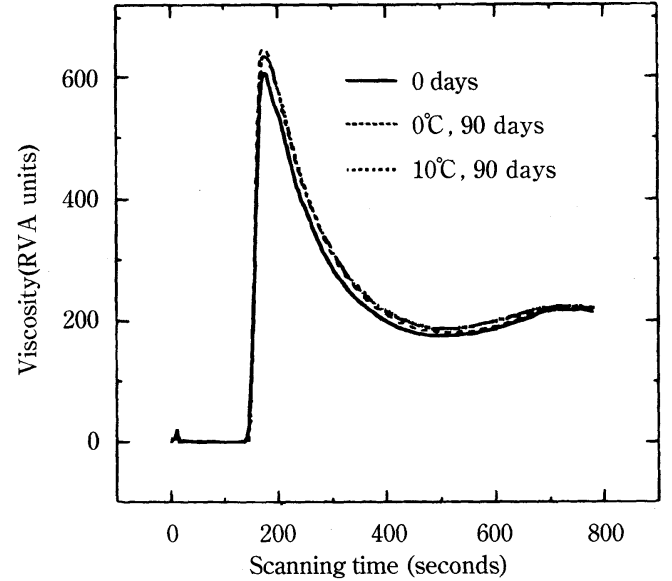

Fig. 6 Viscogram of starch from 'Danshaku' tubers during cold storage.

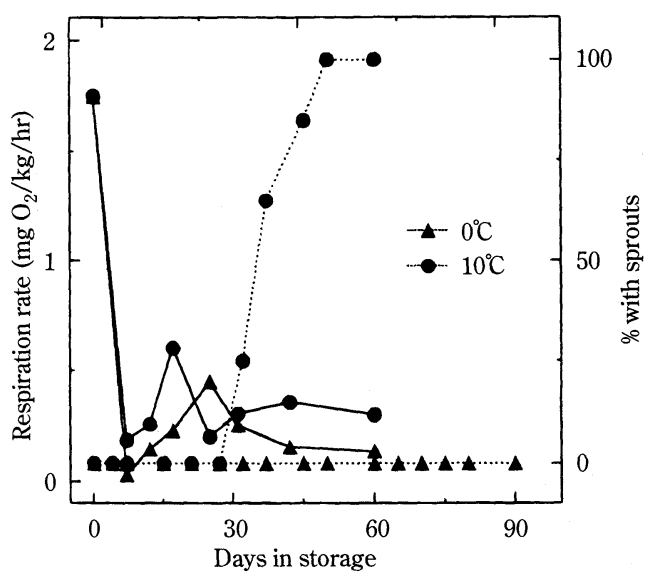

Fig. 7 Respiration and sprouting rate of 'Danshaku' tubers during storage at different temperatures.

Solid lines : respiration rate, dotted lines : sprouting incidence.

causing solubilization and shearing of amylopectin molecules. Hence, the sudden decrease in molecular weight of amylopectin causes the sudden drop in viscosity. Evidence for this is found in experiments where shear was minimal, resulting in extensive granule disruption but no reduction in viscosity even at $130^{\circ} \mathrm{C}^{13}$. Since enzyme attack can disrupt starch structure and result in reduced swelling ${ }^{14)}$, starch from tubers undergoing sprouting or sweetening should 
have lower peak viscosities. However, neither LTS nor sprouting seemed to have any discernible effect on viscosity and pasting properties of starch in 'Danshaku' tubers (Fig. 6).

\section{Sprouting and respiration rate}

Fig. 7 shows the sprouting and respiration profile of tubers during storage at different storage temperatures. Storage at $0^{\circ} \mathrm{C}$ suppressed sprouting completely, while tubers stored at $10^{\circ} \mathrm{C}$ sprouted after 32 days. Respiration rate based on $\mathrm{O}_{2}$ consumption was similarly affected by storage temperature. Prior to storage, respiration rate was $1.75 \mathrm{mg} \mathrm{O}_{2} / \mathrm{kg}$-hr. After 7 days, this had dropped to 0.03 and $0.19 \mathrm{mg} \mathrm{O}_{2} / \mathrm{kg}$-hr for $0^{\circ} \mathrm{C}$ and $10^{\circ} \mathrm{C}$, respectively. A respiratory peak was later observed for all treatments, occurring after 25 and 15 days for tubers stored at $0^{\circ} \mathrm{C}$ and $10^{\circ} \mathrm{C}$, respectively. However, only respiration rates in tubers stored at $0^{\circ} \mathrm{C}$ returned close to basal levels (7-day rates). Respiration in tubers stored at $10^{\circ}$ $\mathrm{C}$ again increased and stayed elevated after 32 days, coinciding with the onset of sprouting. Final respiration rates were 0.14 and $0.30 \mathrm{mg} \mathrm{O}_{2} / \mathrm{kg}-\mathrm{hr}$ for $0^{\circ} \mathrm{C}$ and $10^{\circ} \mathrm{C}$, respectively. This agrees with earlier studies that show an increase in respiration rate occurring with sprouting ${ }^{15}$.

\section{Conclusions}

Storage of 'Danshaku' potatoes at $0^{\circ}$ Cinduced LTS but completely inhibited sprouting and reduced weight loss. Keeping tubers at $10^{\circ} \mathrm{C}$ did not produce LTS but allowed tubers to sprout and produced high rates of weight loss. Starch content decreased in tubers stored at both $0^{\circ} \mathrm{C}$ and $10^{\circ} \mathrm{C}$, due to LTS and sprouting, respectively. However, LTS consumed more starch than sprouting based on greater losses in starch and reduction in starch particle size during $0^{\circ} \mathrm{C}$ storage. Physical quality suffered during storage at $10^{\circ} \mathrm{C}$ as disease and moisture loss caused sprouting, shrivelling, and decay. No significant relationships between sugar levels and specific gravity were observed during storage. Storage at $10^{\circ} \mathrm{C}$ accelerated the onset of sprouting and increased the final respiration rate in 'Danshaku' tubers.

\section{References}

1) Van Es, A. and Hartmans, K. J. : 1987. Starch and sugars during tuberization, storage and sprouting. In: A. Rastovski and A. van Es (eds), Storage of Potatoes. PUDOC, Wageningen. (1987)

2) Lisinska, G. and Leszczynski, W.: Potato Science and Technology. Elsevier Science Publishers, Ltd., Essex. (1989)

3) Knowles, N.R. and Knowles, L. O.: Ann. Botany., 63, 331 338 (1989)

4) Pollock, C. J. and AP Rees, T.: Phytochem., 14, 613 617 (1975)

5) Richardson, D. L., Davies, H. V., Ross, H. A. and Mackay, G. R.: J. Exp. Bot., 41, 95 99. (1975)

6) Amir, J., Kahn, V. and Unterman, M.: Phytochem., 16, 1495 1498 (1975)

7) IsHerwood, F. A.: Phytochem., 12: 2579 2591. (1973)

8) Schippers, P. A.: Amer. Potato J., 48, 234 245. (1971)

9) Toma, R. B., Leung, H. K., Augustin, J. and I RITANI, W. M.: J. Food Sci., 51, 1213 1214 (1986)

10) Hemberg, T.: Potato rest. In: P. H. Li (ed), Potato Physiology. Academic Press Inc.: Florida. (1985)

11) Smith, O: Transport and storage of potatoes. In: W. F. Talburt and O. Smith (eds), Potato Processing. Van Nostrand Reinhold Company, New York. (1987)

12) Buléon, A., Colonna, P., Planchot, V. and B ALL, S.: Int. J. Biol. Macro., 23, 85 112. (1998)

13) Lillford, P. J. and Morrison, A.: Structure/ function relationship of starch is food. In: P. J. Frazer, A.M. Donald, and P. Richmond (eds), Starch Stucture and Functionality. The Royal Society of Chemistry, Cambridge. (1997)

14) Jenkins, P. J. and Donald, A. M.: Starch, 49, 262 267 (1997)

15) Schippers, P. A.: Potato Res., 20, 173 188 (1977) 


\section{低温 $\left(0\right.$ と $\left.10^{\circ} \mathrm{C}\right)$ 貯藏中のジャガイモの品質変化}

村田陽介*・ケビン F.ヤプテンコ**・野口智弘*** .

鈴木敏郎 $* * *$ 佐藤広顕 $* * \cdot$ 松本信二 $* * *$ 高野克已 $*$

$*$ 東京農業大学応用生物科学部生物応用化学科

（テ156-8502 東京都世田谷区桜丘1-1-1）

**東京農業大学生物産業学部食品科学科

（广099-2493 北海道網走市八坂196）

*** 東京農業大学応用生物科学部食品加工技術センター

（テ156-8502 東京都世田谷区桜丘1-1-1）

貯蔵温度の違い $\left(0^{\circ} \mathrm{C}, 10^{\circ} \mathrm{C}\right)$ における男爵薯の物 理的・生化学的変化, すなおち, 塊茎の重量変化, 硬さ,
比重, 色調, 糖, デンプン含量, リン脂質の脂肪酸組成, デンプン粒のサイズ，粘度特性および発芽率と呼吸率の 変化について検討した。その結果, 糖類の蓄積は $0{ }^{\circ} \mathrm{C}$ 貯 蔵でみられたが, $10^{\circ} \mathrm{C}$ 貯蔵においてはほとんどみられ なかった。しかし， $10^{\circ} \mathrm{C}$ 貯蔵では，早い時期からの発 芽と塊茎重量の減少および軟化か顕著に認められた。ま た, $0{ }^{\circ} \mathrm{C}$ 貯蔵に比べ $10^{\circ} \mathrm{C}$ 貯蔵では, 最終呼吸率が高く なっていた。組織の色調については貯蔵温度の影響は受 けなかった。リン脂質の二重結合インデックスは $0{ }^{\circ} \mathrm{C}$, 30 日貯蔵で増加し, 男爵薯の低温ストレス耐性が増加し た。デンプン含量は $0{ }^{\circ} \mathrm{C}$ 貯蔵の方が $10^{\circ} \mathrm{C}$ 貯蔵に比べ減 少が大きく粒子のサイズも小さくなっていたが, 粘度特 性に大きな違いはみられなかった。

(平成12年 3 月 24 日受付，平成 12 年 4 月 24 日受理) 